\title{
NOTES ON GEOGRAPHIC DISTRIBUTION
}

\section{Reptilia, Testudines, Chelidae, Acanthochelys macrocephala: Distribution extension, geographic distribution map, and hatchling morphology}

\author{
Bruno de Oliveira Ferronato ${ }^{1}$ \\ Flavio de Barros Molina 2,3 \\ ${ }^{1}$ Universidade de São Paulo, Escola Superior de Agronomia Luiz de Queiroz, Departamento de Ciências Biológicas. \\ Caixa Postal 09. CEP 13418-900.Piracicaba,SP, Brazil.E-mail: brunoferronato@hotmail.com \\ ${ }^{2}$ Museu de Zoologia da Universidade de São Paulo. \\ Av. Nazaré, 481, Ipiranga. CEP 04263-000. São Paulo, SP, Brazil. \\ ${ }^{3}$ Universidade de Santo Amaro. \\ Rua Professor Enéas de Siqueira Neto, 340, Jardim das Imbuias. CEP 04829-300. São Paulo, SP, Brazil.
}

Acanthochelys macrocephala is a side-necked turtle found in south-central Bolivia, western Brazil and northwestern Paraguay (Rhodin et al. 1984; Iverson 1992). The species is characteristic of South American open formations (Souza 2005), being a typical inhabitant of the Brazilian Pantanal (Alho and Gonçalves 2005; Souza 2005; Junk et al. 2006), Bolivian (Rumiz and Herrera 1998; Dosapey and Montaño 2004) and Paraguayan Chaco (Buskirk 1988; Fritz and Pauler 1992; 1999; Ziegler et al. 2002; Métrailler 2003; 2006; Vinke and Vinke 2001; 2008). It is present in the flooded areas under the influence of the Paraguay river basin (Rhodin et al. 1984; Souza 2005) and possibly the swamplands along the upper Guaporé river (Rhodin et al. 1984). It is also found on the upper Mamoré river drainage (Rhodin et al. 1984; Junk et al. 2006).

The species was described in 1984 based on specimens from one locality in Bolivia and three localities in Brazil (Rhodin et al. 1984). The authors also predicted its occurrence in Paraguay, what four years later was confirmed by Buskirk (1988). Acanthochelys macrocephala was recorded in many other localities in Paraguay (Fritz and Pauler 1992; Ziegler et al. 2002; Métrailler 2003; Weiler 2006, Vinke and Vinke 2001; 2008) and Bolivia (Iverson 1986; Rumiz and Herrera 1998; Dosapey and Montaño 2004) since then. Field work in Brazil added some new localities in the states of Mato Grosso (Cintra and Yamashita 1989; Iverson 1992) and Mato Grosso do Sul (Bour and Pauler 1987; Iverson 1992; Kinas et al. 2005; Ávila et al. 2006). Localities in
Mato Grosso do Sul are restricted to the municipalities of Corumbá, Aquidauana, and possibly Coxim.

In January 2004, one of us (BF) found three hatchlings Acanthochelys macrocephala at the

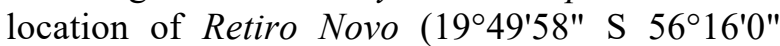
$\mathrm{W}$ ), an area used as invernada (winter pasture for fattening cattle), at Fazenda Caiman, municipality of Miranda, state of Mato Grosso do Sul. This new record is located about $30 \mathrm{~km}$ south from the Fazenda Rio Negro (municipality of Aquidauana, state of Mato Grosso do Sul), where A. macrocephala was previously recorded (Kinas et al. 2005). Hatchlings were photographed and released. Fazenda Caiman is located in the southeastern part of the Brazilian Pantanal, in a subregion known as Aquidauana Pantanal. Dominant vegetation types consist primarily of savannas and semidecidual forests (Silva et al. 2000). This is the first record for the species at municipality of Miranda and represents the southernmost species locality of this species infor Brazil (Figure 1).

Rhodin et al. (1984) described the species based on 15 adult and subadult specimens, being the smallest one a subadult male with a carapace length of $132 \mathrm{~mm}$. Buskirk (1988) was the first to describe a juvenile (carapace length of $93.1 \mathrm{~mm}$ ), based on an empty shell. Other descriptions were made for adults (Cintra and Yamashita 1989; Ernst and Barbour 1989; Fritz and Pauler 1992; Vinke and Vinke 2001; Métrailler 2003; 2006) and juveniles (Métrailler 2003; 2006). Cintra and 


\section{NOTES ON GEOGRAPHIC DISTRIBUTION}

Yamashita (1989) were the first to make a succinct description on a hatchling that measured $38 \mathrm{~mm}$ of carapace length and $27 \mathrm{~mm}$ of plastron length. According to them "the upper part of the carapace, plastron and sides of neck were covered in orange/red patches. The pupils were gray and the iris buff.".

The hatchlings described here measured about 40 $\mathrm{mm}$ of maximum carapace length and $30 \mathrm{~mm}$ of mid line plastron length. The presence of an egg caruncle (Figure 2), an umbilical scar (Figure 3), and some folds in the shell (Figures 3 and 4) indicated that they had only a few weeks of age. There were no concentric growth lines on the carapace and plastron scutes. Plastron anterior lobe was somewhat oval and wider than posterior lobe. Intergular scute was triangular and longer than broad.
The plastral formula was: intergular $>$ femoral $>$ abdominal $>$ humeral $>$ pectoral $>$ anal. The anal notch was angular but not deep (Figure 3). Carapace was oval with maximum width at the level of the 8th marginal scutes. Marginals 3-7 were slightly upturned. Nuchal scute was almost twice as long as broad. Vertebrals were broad, especially vertebrals $2-4$. There was no central groove or keel. There was no supra caudal notch (Figure 4). The head was large. Dorsal surface was covered by large shields of different sizes and irregular shapes (Figure 2). Dorsal surface of neck was covered by very small tubercles. Ventral surface of head and neck was covered by small elongated shields. The chin had two small barbels. Forelimbs had five claws; hind limbs had four claws and large pre-tibial flaps (Figure 3).

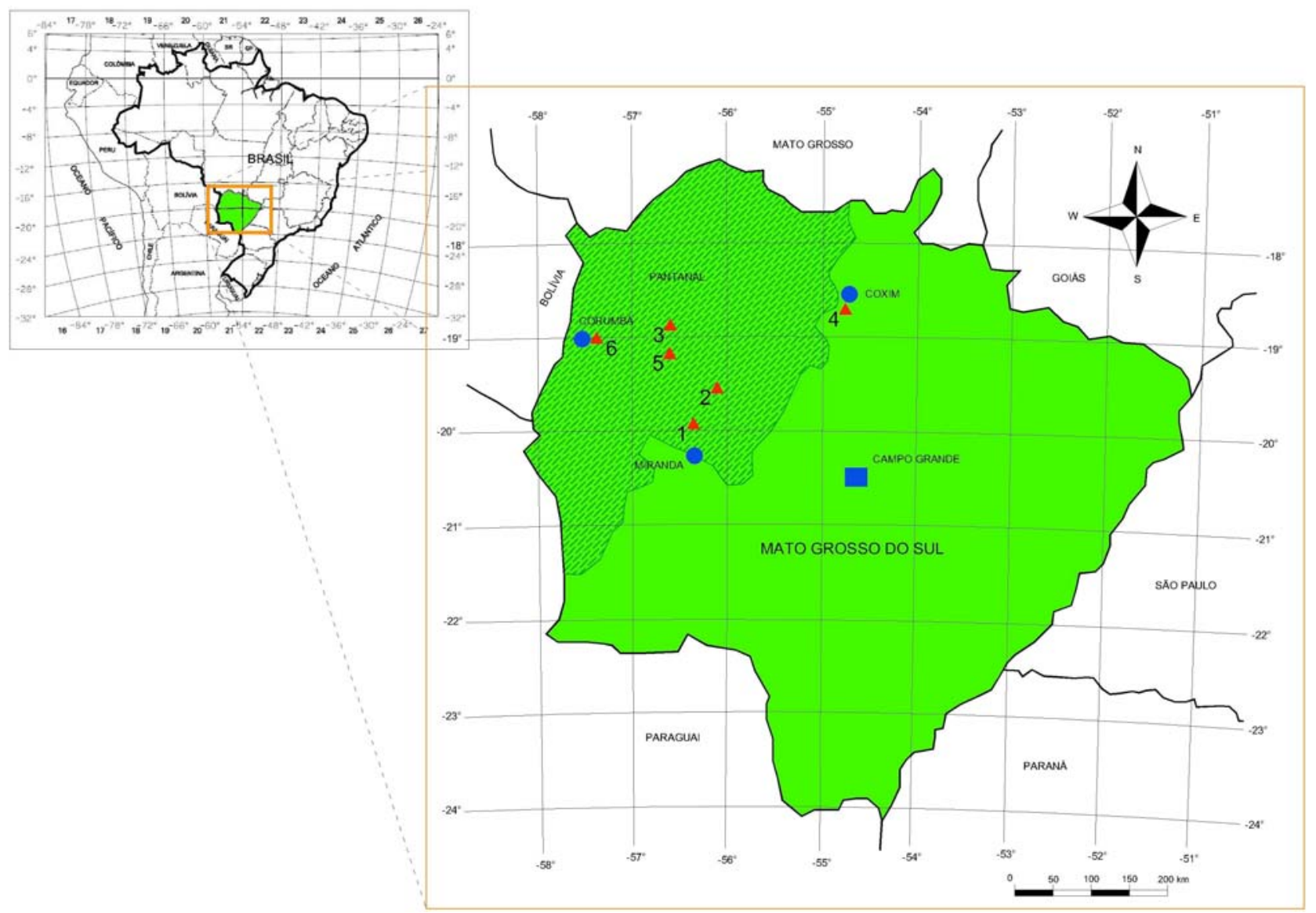

Figure 1. Distribution of Acanthochelys macrocephala in state of Mato Grosso do Sul (Brazil). 1: municipality of Miranda (present study); 2: municipality of Aquidauana (Kinas et al. 2005); 3, 5 and 6: municipality of Corumbá (Bour and Pauler 1987; Kinas et al. 2005; Ávila et al. 2006); 4: municipality of Coxim which deserves further confirmation (Ávila et al. 2006). 


\section{NOTES ON GEOGRAPHIC DISTRIBUTION}

Plastron was black with large orange spots occupying most of the center and external side of each plastral scute, creating a reasonable symmetry between right and left sides (Figure 3). Carapace was brown mottled with black blotches. Large orange spots occupied most of the ventral surfaces of the marginal scutes (Figure 3), including the external border of their dorsal surfaces (Figure 4). Dorsal surface of head was light brown mottled with small black spots. Dorsal surface of neck was black. The tympanum was orange and the iris was pale yellow (Figure 2 ). Ventral surface of head and neck was black with irregular orange markings. The limbs were black with some orange scales and the pre-tibial flaps were orange (Figure 3).
Although the geographic distribution of A. macrocephala is apparently restricted by a well defined seasonal climate with wet and dry seasons and by specific habitat characteristics such as the presence of an open canopy (Souza 2005), further investigation is needed to confirm its presence in other regions and habitat types. The species seems to be associated to low lying swamplands, as no confirmed record is available for upland Brazilian Cerrado sites, which are dominated by seasonal environments and open habitats as well. Altitude and geomorphology seem to be important in shaping $A$. macrocephala distribution. The species is probably absent from the Brazilian plateaus surrounding the Pantanal and Guaporé regions.

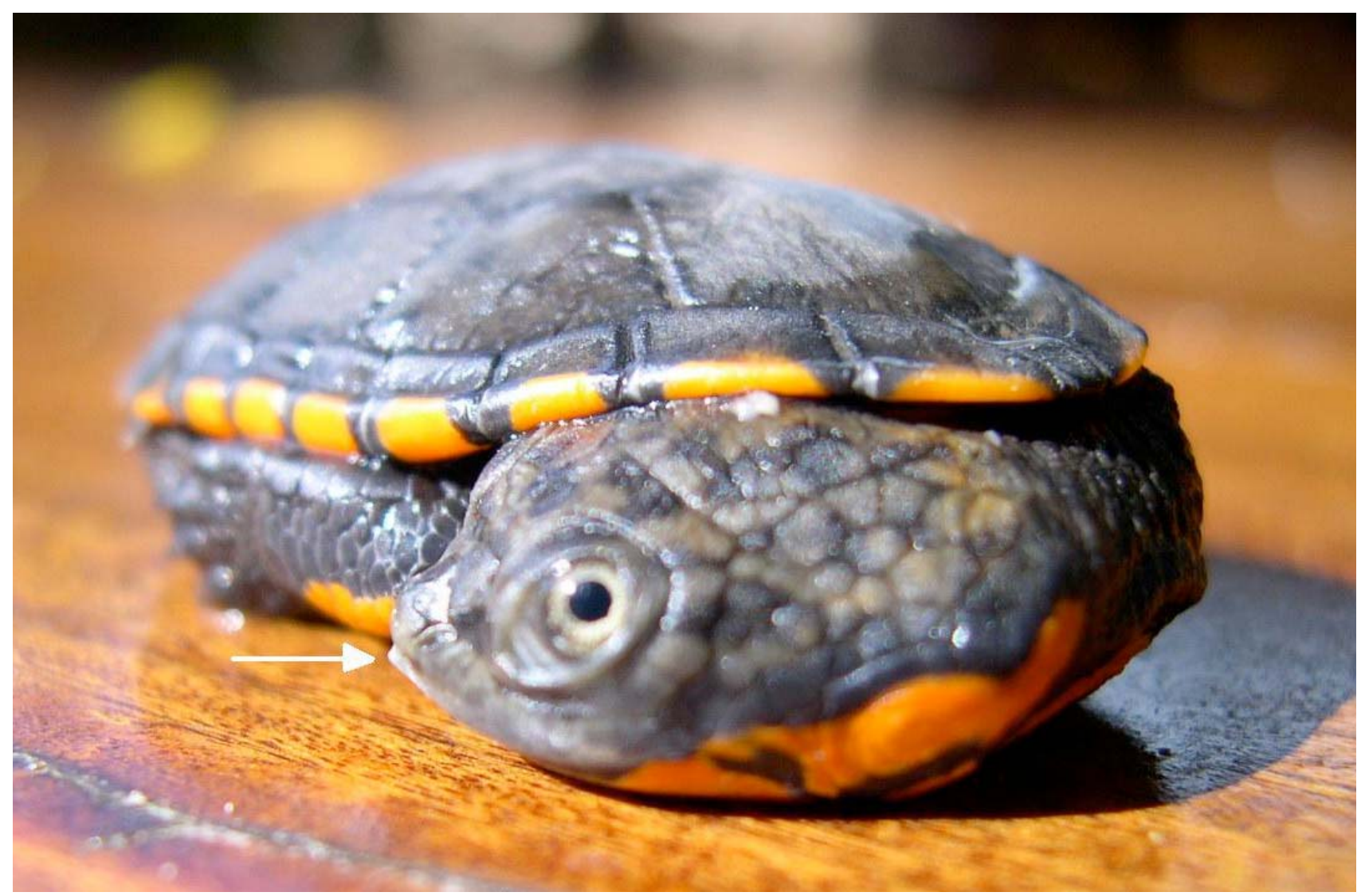

Figure 2. Hatchling of Acanthochelys macrocephala. The arrow points at the egg caruncle. Photo by Fernanda Melo. 
Check List 5(3): 717-722, 2009.

ISSN: $1809-127 \mathrm{X}$

\section{NOTES ON GEOGRAPHIC DISTRIBUTION}

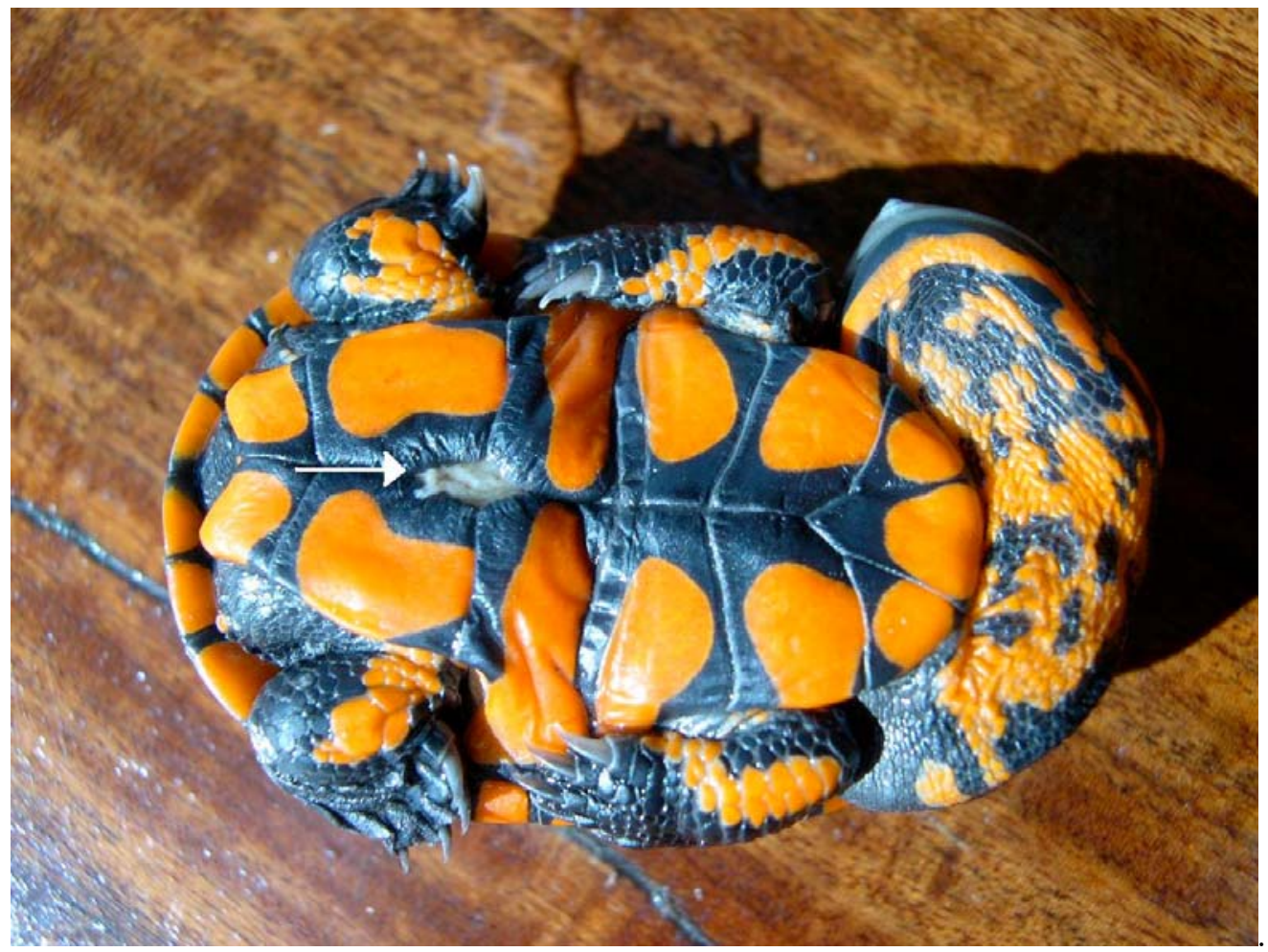

Figure 3. Ventral view of a hatchling of Acanthochelys macrocephala. The arrow points at the umbilical scar. Photo by Fernanda Melo.

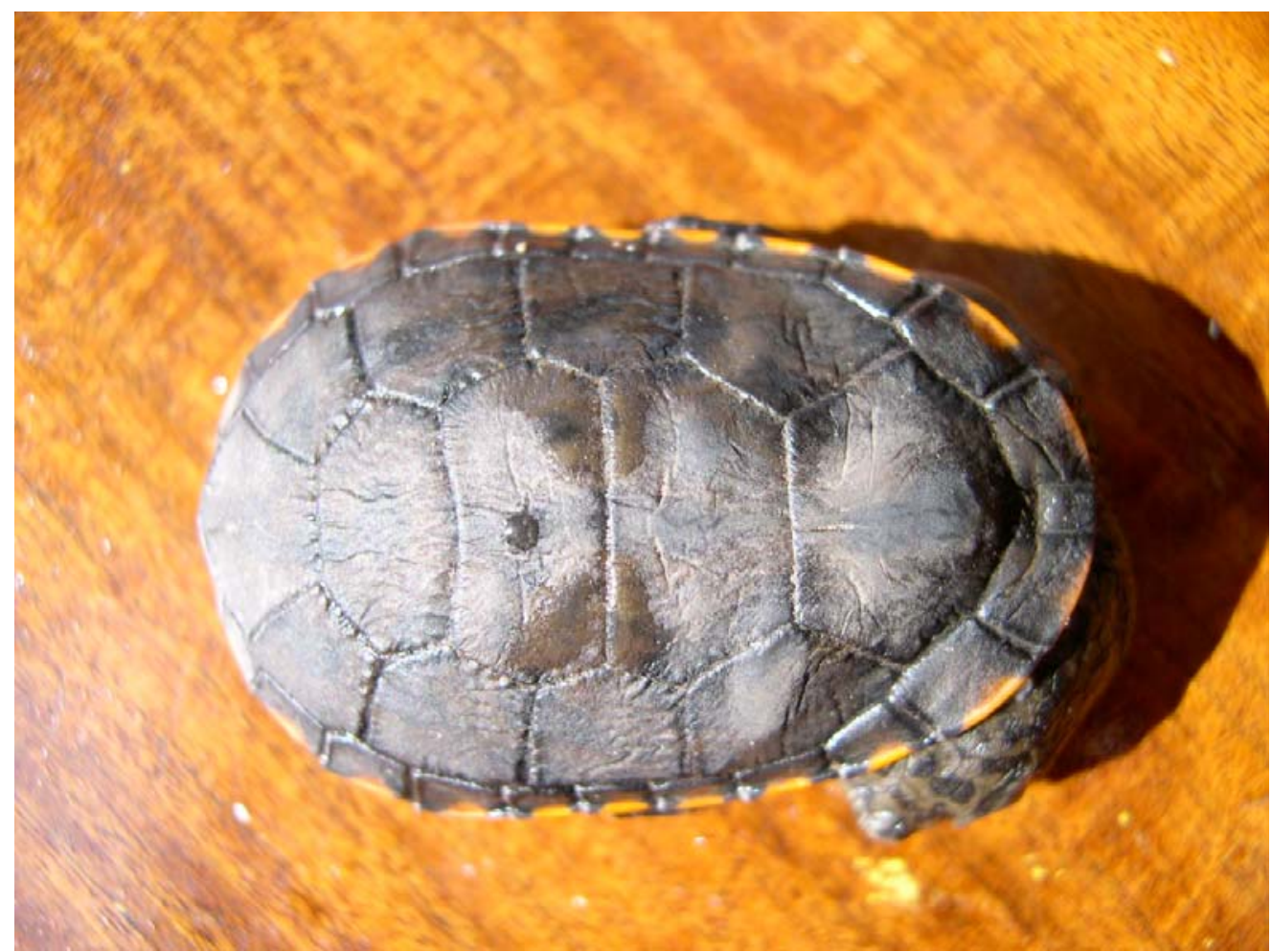

Figure 4. Dorsal view of a hatchling of Acanthochelys macrocephala. Photo by Fernanda Melo. 


\section{NOTES ON GEOGRAPHIC DISTRIBUTION}

\section{Acknowledgments}

We thank the owner and residents of Fazenda Caiman ranch for their support. Fernanda Melo kindly made available her photographs and Sébastién Métrailler helped with bibliography. Franco Leandro de Souza critically reviewed the manuscript. We thank the reviewers' comments and suggestions on this manuscript. Guilherme Ferronato kindly helped with the map design.

\section{Literature cited}

Alho, C. J. R. and H. C. Gonçalves. 2005. Biodiversidade do Pantanal: ecologia e conservação. Campo Grande: Editora UNIDERP. $143 \mathrm{p}$.

Ávila, R. W., F. L. Souza, P. Landgref-Filho, and A. L. C. Campos. 2006. Reptilia, Chelidae, Acanthochelys macrocephala: distribution, habitat, and geographical distribution map. Check List 2(2): 35-37.

Bour, R. and I. Pauler. 1987. Identité de Phrynops vanderhaegei Bour, 1973, et des especes affines (Reptilia - Chelonii - Chelidae). Mesogee 47: 3-23.

Buskirk, J. R. 1988. New locality records in Argentina and Paraguay for chelid turtles, Platemys pallidipectoris (Freiberg) and Platemys macrocephala (Rhodin et al.). Herpetological Review 19(4): 74-75.

Cintra, R. and C. Yamashita. 1989. Notes on the nesting ecology of Platemys macrocephala in the Brazilian Pantanal. Herpetological Review 20(3): 65-66.

Dosapey, T. and F. R. R. Montaño. 2004. Estructura de la población y telemetría de Acanthochelys macrocephala (Testudines, Chelidae) en los humedales del sureste del chaco de Santa Cruz, Bolivia; p. 166-171 In E. Cabrera, C. Mercolli, and R. Resquín (ed.). Memorias: Manejo de Fauna silvestre en Amazonia y Latinoamérica. Iquitos: Editora UNAP.

Ernst, C. H. and R. W. BarBour. 1989. Turtles of the world. Washington DC: Smithsonian Institution Press. 313 p.

Fritz, U. and I. Pauler. 1992. Phrynops chacoensis spec. nov. (Reptilia, Chelidae), eine neue krötenkopfschildkröte. Mitteilungen aus dem Zoologischen Museum in Berlin 68(2): 299307.

Fritz, U. and I. Pauler. 1999. Phrynops chacoensis Fritz \& Pauler, 1992, ein juniorsynonym von Platemys macrocephala Rhodin, Mittermeier
\& McMorris, 1984. Salamandra 35(1): 53-56.

Iverson, J. P. 1986. A checklist with distribution maps of the turtles of the world. Richmond: privately printed. $282 \mathrm{p}$.

Iverson, J. P. 1992. A revised checklist with distribution maps of the turtles of the world. Richmond: privately printed. $358 \mathrm{p}$.

Junk, W. J., C. N. Cunha, K. M. Wantzen, P. Petermann, C. Strüssmann, M. I. Marques, and J. Adis. 2006. Biodiversity and its conservation in the Pantanal of Mato Grosso, Brazil. Aquatic Sciences 68: 278-309.

Kinas, M. A., R. A. Mauro, and F. L. Souza. 2005. Geographic distribution. Acanthochelys macrocephala (Pantanal swamp turtle). Herpetological Review 36(3): 335.

Métrailler, S. 2003. Note sur l'écologie d'Acanthochelys macrocephala (Rhodin, Mittermeier \& McMorris, 1984) au Paraguay (Reptilia, Chelidae). Revue Suisse de Zoologie 110(3): 483-490.

Métrailler, S. 2006. Ecologie de la platémyde à grosse tête (Acanthochelys macrocephala) au Paraguay. Manouria 9(33): 26-32.

Rhodin, A. G. J., R. A. Mittermeier, and J. R. McMorris. 1984. Platemys macrocephala, a new species of chelid turtle from central Bolivia and the Pantanal region of Brazil. Herpetologica 40(1): 38-46.

Rumiz, D. and J. C. Herrera. 1998. La Evaluación de la Fauna Silvestre y su Conservación en Bosques de Producción de Bolivia. Proyecto de Manejo Forestal Sostenible BOLFOR. Electronic Database accessible at http://pdf.dec.org/pdf_docs/Pnacg867.pdf.

Ministerio de Desarrollo Sostenible y Planificación, Santa Cruz, Bolívia. Captured on 25 January 2008.

Silva, M. P., R. Mauro, G. Mourão, and M. Coutinho. 2000. Distribuição e quantificação de classes de vegetação do Pantanal através de 


\section{NOTES ON GEOGRAPHIC DISTRIBUTION}

levantamento aéreo. Revista Brasileira de Botânica 23(2): 143-152.

Souza, F. L. 2005. Geographical distribution patterns of South American side-necked turtles (Chelidae), with emphasis on Brazilian species. Revista Española de Herpetología 19: 33-46.

Vinke, T. and S. Vinke. 2001. The turtle and tortoise fauna of the central Chaco of Paraguay. Radiata 10(3): 3-19.

Vinke, T. and S. Vinke. 2008. Die PantanalPlattschildkröte, Acanthochelys macrocephala, erobert den Dornbuschtrockenwald. Schildkröten im Fokus 5(1): 22-31.

Weiler, A. 2006. Nouvelle localité pour Acanthochelys macrocephala (Rhodin,
Mittermeier \& McMorris, 1984) au Paraguay. Manouria 9(33): 24-25.

Ziegler, T., J. Unger, A. Feiler, and E. Lehr. 2002. The first Gran Chaco Expedition of Museum für Tierkunde Dresden: Records of amphibians, reptiles and mammals from the Dry Chaco of Paraguay (Amphibia, Reptilia, Mammalia). Faunistische Abhandlungen Staatliches Museum für Tierkunde Dresden 23(11): 219-237.

Received August 2008

Accepted September 2009

Published online September 2009 